\title{
Production of functional Turkish noodle (Erişte) supplementary probiotic and determining of some quality properties
}

\author{
Selin Kalkan®, Mustafa Remzi Otağ ${ }^{\circledR}$, Elif İlkay Köksal`, Nursena Şevval Bozkurt@ \\ Cite this article as: \\ Kalkan, S., Otağ M.R., Köksal, E.İ., Bozkurt, N.Ş. (2020). Production of functional Turkish noodle (Erişte) supplementary probiotic and determining of \\ some quality properties. Food and Health, 6(3), 140-150. https://doi.org/10.3153/FH20015
}

Giresun University, Faculty of Engineering, Department of Food Engineering, 28200, Giresun, Turkey

ORCID IDs of the authors:

S.K. 0000-0002-4142-3152

M.R.O. 0000-0001-5450-1546

E.İ.K. 0000-0003-0663-4939

N.Ş.B. 0000-0002-0457-3629

Submitted: 05.11 .2019

Revision requested: 20.01 .2020

Last revision received: 25.01 .2020

Accepted: 09.02.2020

Published online: 25.04 .2020

Correspondence: Selin KALKAN

E-mail: selin.kalkan@giresun.edu.tr

\begin{abstract}
In this study, it was aimed to production Erişte samples which have functional properties by the addition of Bacillus clausii and determined some quality properties. For this purpose, B. clausii was microencapsulated by using extrusion method and added up to $4 \%$ in dough. Dried vegetables were pulverized and then added to the noodles at a rate of 5 to $15 \%$, in order to increase the sensory properties of the noodle samples. In addition, microbiological characteristics and survivor B. clausii for probiotic samples of all noodles samples were analyzed.
\end{abstract}

It was determined that the number of B. clausii was 9.99-11.06 log CFU/g in noodle dough on average; between the values of $9.35-10.11 \log \mathrm{CFU} / \mathrm{g}$ after shaping the noodles; after cooking the noodles samples, it was determined that they ranged between $5.02-5.10 \log \mathrm{CFU} / \mathrm{g}$ values. $B$. clausii values were sufficient to maintain the resistance of probiotic microorganisms in the gastrointestinal system. The enriched products by probiotic are in the nature of functional new product in accordance with the purpose of the study.

Keywords: Turkish noodle, Probiotic, B. clasuii, Quality, Functional product

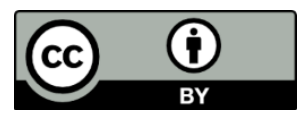

(C) Copyright 2020 by ScientificWebJournals Available online at http://jfhs.scientificwebjournals.com 


\section{Introduction}

Humanity is providing the nutrients necessary for survival and social functioning from the vegetable and animal origin foodstuffs. Healthy nourishment can be achieved by taking these two groups of food materials in sufficient and balanced amounts (Martín et al., 2015). In Turkey, as in many parts of the world, many daily calories from grains and grain products are provided. Pasta products are highly preferred due to its low price, easy preparation, the wide variety of uses, flavor characteristics, and long shelf life (Bergman et al., 1994). Noodles are a primary food in much of the world, especially East Asia. Erişte (Noodles) is a food product originating from China and promoted to the whole world through the silk road. The prepared mix can be directly consumed after kneading, drying, boiling and cooking (Gunathilake and Abeyrathne, 2008). The quality of Erişte is assessed as a combination of their appearance, texture, and cooking properties (Zhang et al., 2015). It is the main goal of food production to provide safe and nutritious food that will ensure the healthy and happy life for people (Siró et al., 2008). In recent years, the changing of the nutritional characteristics of consumers, the increase in expectations of life expectancy of consumers, the development of healthy nutrition awareness, and the increase in obesity and other health problems have become effective at increasing of consumption of "functional food product" (Granato et al., 2010). The use of probiotic microorganisms to gain functional properties of foods has become more intense in recent years with the increase in demand for prebiotic products. Probiotics are live microbial sources that have a beneficial effect on human health by modifying the natural gut microbiota positively. Probiotic starter culture is a single or mixed culture that creates the mentioned effects (Parvez et al., 2006). The minimum number of probiotic bacteria in the product is $10^{6}-10^{8} \mathrm{CFU} / \mathrm{ml}$ in order for probiotic bacteria to have a beneficial effect (Schrezenmeier and De Vrese 2001). Although it is important for probiotic bacteria to maintain the number of live cells in food, these bacteria have lost their vitality during the shelf life of the product for whatever reasons. Therefore, various strategies for increasing the viability and continuity of probiotic bacteria in products are constituted the focus of recent studies (Vinderola et al., 2000). Also, various techniques are applied to maintain and support the viability of probiotic cultures in product development (Ross et al., 2002). One of these techniques is microencapsulation. Microencapsulation (ME) can be defined as packaging by using protein or carbohydrate-based coating material of solid, liquid or gaseous food components, enzymes, microorganisms, cells and other substances (Gouin, 2004; Madene et al., 2006). Various techniques are used to form capsules in the ME process. Among these methods, spray drying, emulsion and extrusion methods are mostly used in probiotic foods
(Iyer and Kailasapathy, 2005; Chen and Chen, 2007). Bacillus spp. which known as probiotic is used in nutritional supplements for humans, incentives to grow for the animals, and growth regulators or resistance to diseases for aquatic products. There are probiotic Bacillus spp. products that are produced and sold in the United States (USA), European and Asian countries. Although the Bacillus species have been used for about 50 years under the name of a medical support product, the scientific studies on this subject have been around for the last 15 years. Bacillus species that are studied the most are Bacillus subtilis, Bacillus clausii, Bacillus cereus, Bacillus coagulans, Bacillus licheniformis, Bacillus pumilus and Bacillus laterosporus. Bacillus species are mostly safe, but, strains that produce enterotoxin and/or emetic toxin and contain an infectious antibiotic resistance agent may cause problems (Sorokulova et al., 2008; Cutting, 2011). It is known that Bacillus clausii has a direct effect by releasing antimicrobial substances against gram-positive pathogenic bacteria such as Staphylococcus aureus, Enterococcus faecium, and Clostridium difficile. B. clausii spores, which are taken orally, pass through the stomach-gall bladder due to its high resistance to chemical and physical influences, reaching intestinally intact. Here, it shows a number of beneficial effects aimed at regrowing under appropriate conditions and restoring the physiological balance of the flora. Thus, $B$. clausii helps to regulate the digestive tract and support the immune system. B. clausii can synthesize antimicrobial agents like bacteriocins that restrict the growth of various pathogenic bacteria. It also affects the immune system by stimulating the growth of antibodies (Cutting, 2011).

Scientific studies on this subject have been conducted over the last decade, although there are probiotics containing spore-forming bacteria such as Bacillus and commercially available products and so there are still some unexplained things about this subject such as safety of uses. For this reason, detailed studies must be done so that Bacillus species can be used as potential probiotic products for human consumption. The aim of this study was to investigate the potential use of $B$. clausii strains known to be probiotic in the production of Erişte among the most consumed foods. For this purpose, the chemical, physical, microbiological and sensory properties of Erişte samples produced have been determined. Thus, it is aimed to increase the production potential of probiotic Erişte which is beneficial to consumer health by protecting or improving the intestinal microbial balance of individuals and to develop a functional new product. 


\section{Materials and Methods}

\section{Microencapsulation of Bacillus clausii}

Bacillus clausii T strain (Enterogermina; Sanofi, Italy) was used as a probiotic culture in the study. Alginate microcapsules were obtained using a modified encapsulation method of Kalkan et al. (2018); Chen et al. (2007). Accordingly, the $B$. clasuii culture concentrates, which was grown in $20 \mathrm{ml}$ $\left(10^{9} \mathrm{CFU} / \mathrm{ml}\right)$ was slowly added and immobilized to a solution of $80 \mathrm{ml}$ sterile alginate containing $2.5 \%$ sodium alginate for about 10 min using a magnetic stirrer. In this way, the bacteria were dispersed into the alginate solution. The obtained alginate bacterial suspension provides the alginate to form a spherical bead in the gel $500 \mathrm{ml} 0.2 \mathrm{M} \mathrm{CaCl}_{2}$ solution was extruded by dropwise transfer of the distance to $30 \mathrm{~cm}$ with sterile $21 \mathrm{G}$ syringe. When the droplets were dripped into the $\mathrm{CaCl}_{2}$ solution, the cross-ionic binding takes place and the cells were trapped in the 3D mesh structure and the alginate encapsulation (microcapsules) was performed (Karthikeyan et al., 2014). The resulting calcium alginate microcapsules were additionally mixed in $\mathrm{CaCl}_{2}$ solution for 30 $\mathrm{min}$ in a magnetic stirrer to provide a more rigid and robust form of the capsules and then the capsules were washed in sterile pure water (Chen et al., 2007). Finally, filtration was performed using Whatmann filter paper No.4 to obtain microcapsules in $\mathrm{CaCl}_{2}$ solution. Microencapsulated probiotic culture was shown in Figure 1.

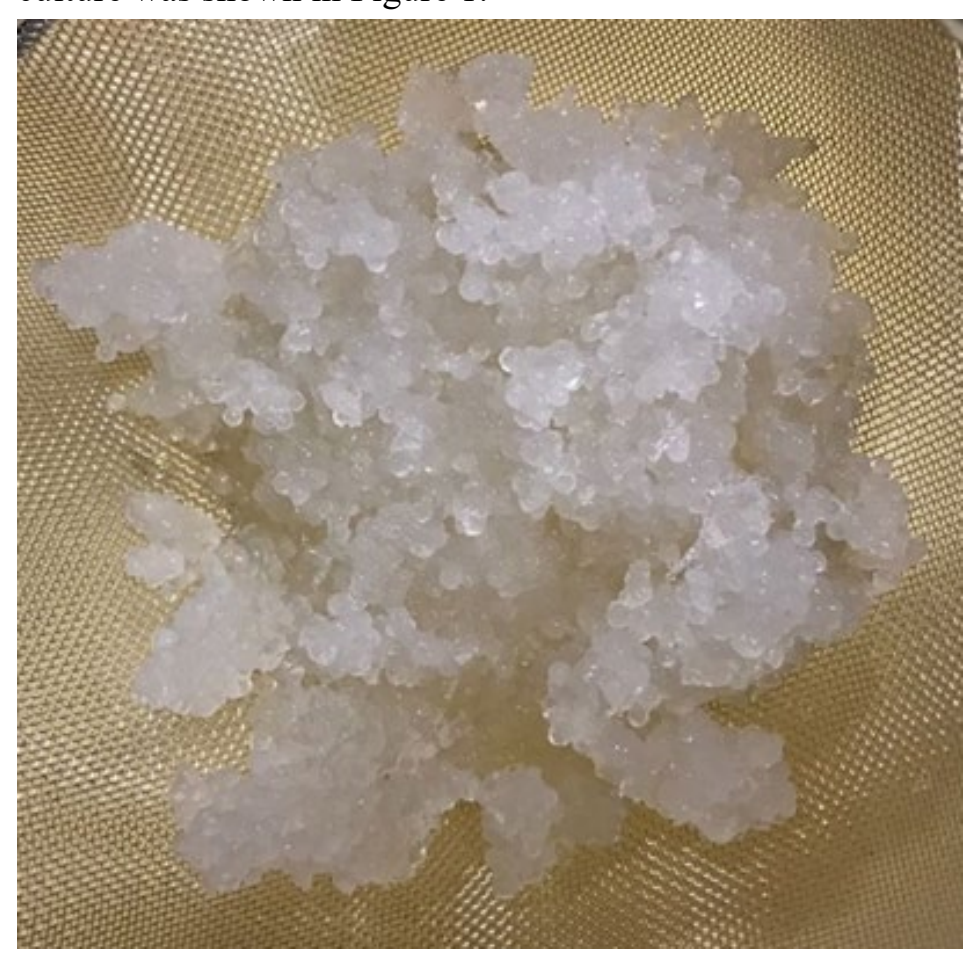

Figure 1. Microencapsulated probiotic B. clausii culture

\section{Production of Erişte}

All materials used in Erişte samples production were supplied from local grocery stores in Giresun. Erişte samples were prepared according to the method reported by Demir et al. (2010). For preparation control group (plain samples; without vegetable powder and microencapsulated $B$. clausii), $300 \mathrm{~g}$ wheat flour, $1 \mathrm{~g}$ salt, 2 pieces whole eggs, $30 \mathrm{ml}$ milk and 50 $\mathrm{ml}$ water were mixed in mixer (Kiwi kmx 3633, Turkey) for $10 \mathrm{~min}$. Then the Erişte dough was divided into four pieces (Control (A), Probiotic-Control (B), Control-added dried vegetable powder $(\mathrm{C})$ and Probiotic-added vegetable powder (D), covered with cloth and rested for $30 \mathrm{~min}$ at room temperature. At the end of this period, the Erişte dough pieces were sheeted with a rolling pin. Then, the dough was sheeted at a thickness of about $2 \mathrm{~mm}$ and cut with a noodle machine (Maracato Ampia 180, Italy). Drying was made in a drying cabinet (Nüve FN 120, Turkey) at $50^{\circ} \mathrm{C}$ for $18 \mathrm{~h}$. B. clausii was microencapsulated by using extrusion method and used in Probiotic Erişte production as 4\% rate. For the production of vegetable Erişte, spinach, carrots, tomatoes and red berry vegetables, thoroughly cleaned and washed, are dried at $40^{\circ} \mathrm{C}$ (Nüve FN 120, Turkey) and powdered by grinding (Waring Blender 7011HS, Osaka Chemical Co. Ltd., Japan) with 60 mesh particul size. After Erişte production, all groups were stored at room temperature to be used in analysis by applying vacuum packaging.

\section{Chemical analysis}

Chemical components of Erişte samples were determined using Standard Methods (International Association for Cereal Science and Technology-ICC, 1992), for the determination of moisture, ash and protein. Water activity and acidity values of Erişte samples were determined according to $\mathrm{Li}$ et al. (2011) and Lu et al. (2003)

\section{Color}

Colors of Erişte samples were evaluated by measuring the $L^{*}$ (whiteness/darkness), $a^{*}$ (redness /greenness) and $b^{*}$ (yellowness / blueness) parameters using Minolta CR-410 (Minolta Chroma, Osaka, Japan) (Ugarčić-Hardi et al., 2007).

\section{Cooking Quality}

Cooking quality parameters such as cooking time and volume increase were determined according to Demir et al. (2010). In order to determine the cooking time of the Erişte samples, 78 minutes after the sample was started to be cooked in the beaker, a piece with a collet holder was taken and squeezed between glass plates. This process was continued for one minute until the light colored uncooked part in the center of the oppressed glass between the glass plates was no longer visible and the time elapsed from the beginning until that moment 
was determined. Volume increase of samples was determined by the volume difference of water overflow when the cooked and dry Erişte sample was put into the water full graduated cylinders. Erişte samples $(10 \mathrm{~g})$ were cooked in $100 \mathrm{ml}$ boiling water for $5 \mathrm{~min}$ and drained for $5 \mathrm{~min}$. The drained Erişte were weighed to determine the cooking weight gain, which was expressed as a percentage of the initial dry matter. The cooked Erişte was collected and dried in an air oven at 115 ${ }^{\circ} \mathrm{C}$. The remaining solids were weighed to determine the cooking loss which was expressed as a percentage of the initial dry matter (Li et al., 2018).

\section{Microbiological Analysis}

Total bacteria, yeast and mold, Coliforms and Staphylococcus spp. analyses were made for determining microbial contamination levels of Erişte samples. Petri dishes were incubated for the mesophilic aerobic bacteria count at $30^{\circ} \mathrm{C}$ for 48 hours by using Plate Count Agar (PCA, Merck), for yeast and mold count at $30^{\circ} \mathrm{C}$ for 72 hours by using Potato Dextrose Agar (PDA, Merck), for coliform bacteria at $37^{\circ} \mathrm{C}$ for 24 hours by using Fluoracult Violet Red Bile Agar (FVRB, Merck) and for Staphylococcus spp. at $37^{\circ} \mathrm{C}$ for $24 \mathrm{hr}$ by using Baird Parker Agar (BPA, Merck). The number of bacteria in the sample was designated as CFU/g by determining the number of colonies developing after incubation (FDA Manuel, 1995). Mueller Hinton Broth (Merck) broth was used for the activation of $B$. clausii cultures. Petri dishes were incubated at $37^{\circ} \mathrm{C}$ for $24 \mathrm{~h}$ and counting results were obtained after spreading and cultivation in MYP Agar (Merck) and Mueller Hinton Agar (Merck) media (Urdaci et al., 2004).

\section{Sensory Analysis}

For sensory analysis, $100 \mathrm{~g}$ Erişte samples were simmered at $95^{\circ} \mathrm{C}$ in $500 \mathrm{ml}$ water for $20 \mathrm{~min}$. and drained for $20 \mathrm{~s}$ to remove excess water. The evaluation of the opinions of 8 panelists who are working at Food Engineering Department of Giresun University, Turkey was reported for sensory properties. They were asked to score the resulting cooked Erişte based on color, taste, chewiness, cooking properties and odor criterion using a 5-point scale.

\section{Statistical analysis}

The obtained data from all the analysis were exposed to the analysis of variance in the study by using IBM SPSS Statistic 19.0 software (IBM Corporation, Somers, NY, USA). Duncan's multiple range tests at $(\mathrm{p} \leq 0.05)$ level was used to compare between means (Demir et. al., 2010).

\section{Results and Discussion}

\section{Chemical Properties of Erişte}

The chemical properties of the Erişte samples produced are shown in Table 1. As shown in Table 1, when the humidity values of control-plain Erişte (A) and control group vegetables (C) Erişte were compared, it was observed that there was a decrease in moisture content of vegetable-flavored group. It was deduced that this decrease in moisture content was related to the increase in the amount of dry matter due to the addition of vegetable powders. When the moisture values of probiotic plain (B) and probiotic vegetable (D) Erişte samples were examined, it was observed that the vegetable Erişte samples showed a better drying rate compared to the plain groups. This was thought to be due to both the addition of probiotic and the addition of vegetable powders. When the moisture content levels of both groups (plain and with vegetable powders adjuvant) were compared, the addition of vegetable powders reduced the moisture values. Moisture content is an important criterion in the accesses and informs about whether the drying process is complete or not. At the same time, the moisture content in the final product is a very important parameter in terms of product safety and commercial value. The moisture content of all Erişte samples was determined below the $13 \%$ (Rajam et al., 2015). Similar results were obtained with moisture levels reported by Rajam et al. (2015). From these data, it can be said that the drying was done well, the formulation was in conformity with the standards. Rajam et al. (2015) reported that the moisture content of Erişte samples was found to be between $4.34-6.67 \%$, similar to our study results.

Table 1. Chemical properties of Erişte (noodle) samples

\begin{tabular}{lcccc}
\hline \multirow{2}{*}{ Chemical analyzes } & \multicolumn{4}{c}{ Groups* $^{*}$} \\
\cline { 2 - 5 } & $\mathbf{A}$ & $\mathbf{B}$ & $\mathbf{C}$ & D \\
\hline Moisture (\%) & $10.17 \pm 0.47^{\mathrm{d}}$ & $9.16 \pm 0.48^{\mathrm{c}}$ & $7.49 \pm 0.17^{\mathrm{a}}$ & $8.57 \pm 0.21^{\mathrm{b}}$ \\
Water activity & $0.54 \pm 0.02^{\mathrm{b}}$ & $0.51 \pm 0.00^{\mathrm{b}}$ & $0.46 \pm 0.00^{\mathrm{a}}$ & $0.54 \pm 0.02^{\mathrm{b}}$ \\
Acidity (\%) & $0.17 \pm 0.04^{\mathrm{b}}$ & $0.12 \pm 0.01^{\mathrm{a}}$ & $0.19 \pm 0.00^{\mathrm{b}}$ & $0.31 \pm 0.00^{\mathrm{c}}$ \\
Protein (\%) & $10.56 \pm 1.08^{\mathrm{a}}$ & $10.74 \pm 0.54^{\mathrm{a}}$ & $12.15 \pm 0.72^{\mathrm{b}}$ & $12.23 \pm 1.12^{\mathrm{b}}$ \\
Ash (\%) & $1.09 \pm 0.05^{\mathrm{a}}$ & $1.00 \pm 0.09^{\mathrm{a}}$ & $2.13 \pm 0.07^{\mathrm{b}}$ & $2.12 \pm 0.09^{\mathrm{b}}$ \\
\hline
\end{tabular}

*A: control-plain Erişte; B: probiotic-plain Erişte ; C: control-vegetables Erişte; D: probiotic-vegetable Erişte; a-d: Means in the same row with different letters differ significantly at * $P \leq 0.05$. 
It was found that water activity values were related to the moisture content when the water activity values given in Table 1 of the Erişte samples were examined. As expected, the lowest water activity value in the control-vegetable Erişte samples was determined with the lowest value of moisture $(7.79 \%)$. Also, it was found that the control-plain group Erişte samples with the highest moisture content at $10.17 \%$ have been the highest water activity value. When the acidity values of the samples shown in Table 1 were examined, it is seen that acidity values have increased in the Erişte samples enriched with the addition of vegetable powder. It was thought that this situation is related to the presence of high organic acids in vegetable powders. The data obtained from all Erişte samples indicates that the acidity values are above the $0.05 \%$. It was thought that this may be caused by lactic acid bacteria contaminated from the environment in raw milk used in production. Baiano et al. (2008), in a similar study, was determined that the acidity values of the samples were between 0.054 and $0.076 \%$ in the Traditional Italian pasta. It was determined that the highest protein content was obtained in probiotic vegetable Erişte samples when protein ratios (\%) of the produced Erişte samples were evaluated. $\mathrm{Hu}$ et al. (2007) similar to the values obtained in our study, reported that the protein ratio of Erişte samples ranged from 10.70 to $1.63 \%$. According to the Filip and Vidrih (2015), the protein content of plain and enriched pasta should be at least $12 \%$ and protein values obtained in our study were suitable for the notification. As shown in Table 1, the ash values of the Erişte samples (\%) were found range from $1.00-2.13 \%$. The increase in the ash values of the samples with the addition of vegetable powder to Erişte showed parallelism. It is more suitable to use flour obtained from wheat, which has $1.4 \%$ or less ash content in Erişte production. In general, for Erişte production, flours with ash less than $0.5 \%$ are required. However, this ratio should be $0.4 \%$ or less for better quality Erişte
(Hou and Kruk, 1998). Izydorczyk et al. (2005) stated that the ash values of the Erişte samples were found to be 0.44-1.06 $\%$ similar to our study.

\section{Color Parameters of Erişte}

The color values $\left(L^{*}, a^{*}\right.$ and $\left.b^{*}\right)$ of the Erişte samples were shown in Table 2 . Erişte color is significantly affected by protein and ash content of flour with the addition of eggs (Pomeranz, 1998). In terms of Erişte quality and consumer preferences, the bright yellow appearance of Erişte is an important parameter (Ozyurt et al., 2015). When the color values of the produced Erişte samples were examined, it was determined that the addition of vegetable powder caused significant changes in color values $(\mathrm{p} \leq 0.05)$.

The highest $L^{*}$ values were found with the probiotic-plain samples and control-plain samples. The lowest $L^{*}$ values (higher brownness) were found with the control-vegetables Erişte and probiotic-vegetable Erişte. It can be explained by the higher content of ash and dietary fibre. The highest $a^{*}$ values were determined to control-vegetable Erişte, and the lowest $a^{*}$ value was found with the control-plain Erişte samples. The highest $b^{*}$ values were observed in samples B. Despite the high value of the $b^{*}$ parameter is desirable for pasta color scoring. Ugarčić-Hardi et al. (2007), in a similar study, reported that $L^{*}$ values were as $63.8-78.9 ; a^{*}$ values were as $-3.4-1.5 ; b^{*}$ values were as $12.9-27.0$ and $\Delta E^{*}$ values were as 2.3-15.2 for fresh Erişte. In the same study, $L^{*}$ values were as 66.8-76.6; a values were as $(-2.4)-1.7 ; b^{*}$ values were as 12.7-26.4 and $\Delta E^{*}$ values were as 3.8-9.8 for dried Erişte. Demir et al. (2010), in another similar study, determined that $L^{*}$ values were as $81.078-85.547 ; a^{*}$ values were as $0.373-$ $0.381 ; a^{*}$ values were as $12.907-16.254$ for some raw materials used in Erişte samples.

Table 2. Color values of Erişte (noodle) samples

\begin{tabular}{|c|c|c|c|c|}
\hline \multirow{2}{*}{ Color values } & \multicolumn{4}{|c|}{ Groups* } \\
\hline & $\mathbf{A}$ & B & $\mathbf{C}$ & D \\
\hline$L^{*}$ & $62.22 \pm 2.19^{b}$ & $72.52 \pm 2.17^{\mathrm{bc}}$ & $43.09 \pm 0.99^{\mathrm{a}}$ & $48.28 \pm 2.79^{\mathrm{a}}$ \\
\hline$a^{*}$ & $6.36 \pm 0.36^{\mathrm{a}}$ & $7.14 \pm 0.50^{\mathrm{b}}$ & $11.57 \pm 0.16^{\mathrm{d}}$ & $9.98 \pm 0.29^{c}$ \\
\hline$b^{*}$ & $34.65 \pm 1.76^{\mathrm{bc}}$ & $38.79 \pm 1.91^{\mathrm{c}}$ & $31.59 \pm 1.29^{b}$ & $22.94 \pm 1.99^{\mathrm{a}}$ \\
\hline
\end{tabular}

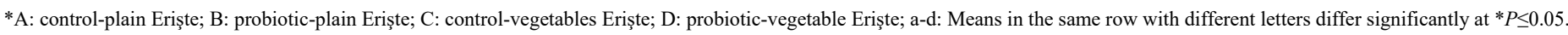




\section{Cooking Characteristics}

The results of cooking analyzes of the Erişte samples were shown in Table 3. The cooking quality of Erişte is one of the important criteria for the evaluation of Erişte quality. The average cooking time of Erişte samples was found between 7 and $9 \mathrm{~min}$. The shortest cooking time was determined as 7 min in the control group vegetable Erişte. Optimal cooking time is mainly based on water transfer and starch gelatinization. The weak protein network facilitates the penetration of water into starch (Sozer and Kaya, 2008). The volume increase was found to be between 201.67 and $208.67 \%$ on average. A good quality pasta should draw at least 2 times its weight and swell 3-4 times its volume (Pinarlı et al., 2004). All Erişte samples analyzed were found to be good quality in terms of volume increase. Similarly, Demir et al. (2010) reported that volume increase values were found to be between 201.79 and $211.87 \%$. Weight increase values of Erişte samples were determined between 193.66-202.33\%. As known, the higher the amount of protein, the lower the water absorption value. This is because of the strong protein network is the prevention of water diffusion of starch granules. The high protein content is not effective on the quality of baking of Erişte alone. Protein quality, as well as protein amount, is very important (Shewry, 2007). Similarly, Li et al. (2018) was stated that weight increase values of Erişte samples were determined between $159-203 \%$.

\section{Microbial Properties of Erişte}

Microbiological analysis (total mesophilic aerobic bacteriaTMAB, total coliform, and yeast-mold and $S$. aureus) results of Erişte samples were shown in Figure 2. As shown in Figure 2 , there was a higher number of TMAB numbers of probiotic groups than in control groups. This result is thought to be caused by the B. clausii strains used for the production of probiotic Erişte. Also, when compared to the plain groups and the vegetable powder-added Erişte samples in terms of TMAB count, it was determined that vegetable powder supplemented groups contained a higher number of TMAB. This situation is considered to be a result of the addition of vegetable powder because of lactic acid bacteria. The maximum acceptable limit is $(6.0 \mathrm{CFU} / \mathrm{g})$ for the TMAB in the fresh noodles (Ghaffar et al., 2009). It may be considered as a reference point between spoiled and unspoiled noodles.

Table 3. Cooking properties of Erişte (noodle) samples

\begin{tabular}{lcccc}
\hline \multirow{2}{*}{ Cooking properties } & \multicolumn{4}{c}{ Groups* $^{*}$} \\
\cline { 2 - 5 } & $\mathbf{A}$ & $\mathbf{B}$ & $\mathbf{C}$ & D \\
\hline Cooking time (min) & $9.00 \pm 0.00^{\mathrm{b}}$ & $9.00 \pm 0.00^{\mathrm{b}}$ & $7.00 \pm 0.00^{\mathrm{a}}$ & $8.00 \pm 0.00^{\mathrm{ab}}$ \\
Volume increase (\%) & $203.00 \pm 2.64^{\mathrm{ab}}$ & $208.67 \pm 7.09^{\mathrm{b}}$ & $201.67 \pm 2.68^{\mathrm{a}}$ & $202.00 \pm 2.64^{\mathrm{a}}$ \\
Weight increase (\%) & $198.66 \pm 2.51^{\mathrm{ab}}$ & $193.66 \pm 4.04^{\mathrm{a}}$ & $202.33 \pm 7.50^{\mathrm{bc}}$ & $200.66 \pm 3.78^{\mathrm{b}}$ \\
Cooking loss (\%) & $7.86 \pm 0.50^{\mathrm{a}}$ & $8.05 \pm 0.51^{\mathrm{ab}}$ & $8.74 \pm 1.93^{\mathrm{b}}$ & $8.77 \pm 0.22^{\mathrm{b}}$ \\
\hline
\end{tabular}

*A: control-plain Erişte; B: probiotic-plain Erişte; C: control-vegetables Erişte; D: probiotic-vegetable Erişte ; a-c: Means in the same row with different letters differ significantly at * $P \leq 0.05$. 


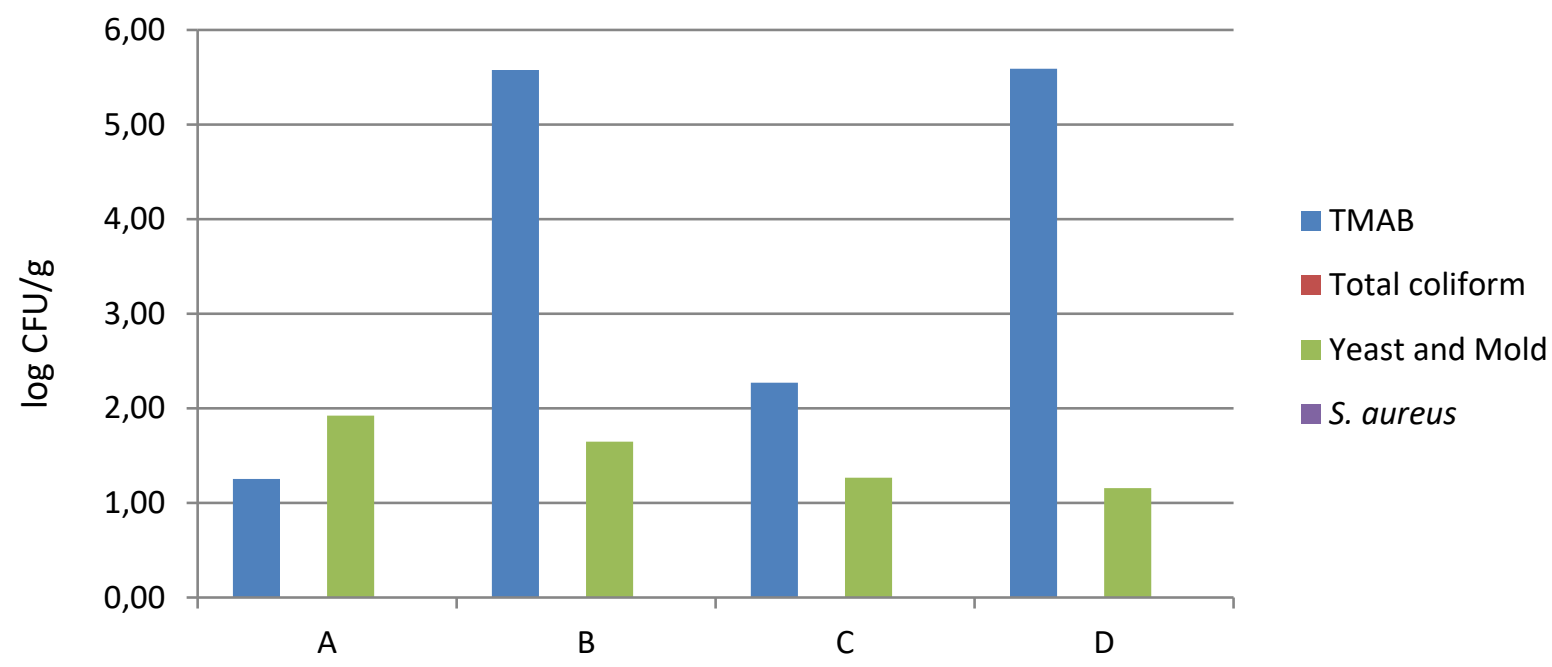

Erişte (noodle) samples

Figure 2. Microbial properties of Erişte (noodle) samples

It was determined that none of the samples were found to contain Staphylococcus aureus and coliform group microorganisms in our study. It may be due to the lower water activity and hygienic handling and packaging of products. When the samples of prepared Erişte were evaluated in terms of the number of yeast-mold, no significant differences were determined between the samples. It is thought that the drying process applied to the Erişte after shaping the dough reduces the moisture content in the dough and the decrease in the yeast and mold content of the Erişte as a result of the low water activity values. Yeast and mould count was much lower than the acceptable limit for fresh pasta, i.e. $4 \log \mathrm{CFU} / \mathrm{g}$ (WHO, 2000).

In order to improve the functional properties of Erişte samples, the addition of $B$. clausii has been investigated and it has been determined that $B$. clausii maintains the presence of probiotic properties in all process stages. The number of $B$. clausii of probiotic Erişte samples was shown in Figure 3. As shown in Figure 3, it was determined that the number of $B$. clausii was 9.99-11.06 log CFU/g in Erişte dough on average; between the values of $9.35-10.11 \log \mathrm{CFU} / \mathrm{g}$ after shaping the Erişte; between 5.97 and $6.95 \log \mathrm{CFU} / \mathrm{g}$ values after drying $\left(50{ }^{\circ} \mathrm{C}\right)$ the Erişte samples; after cooking (at $90{ }^{\circ} \mathrm{C}$ during $10 \mathrm{~min}$ ) the Erişte samples, it was determined that they ranged between 5.02 - $5.10 \log \mathrm{CFU} / \mathrm{g}$ values. These values were sufficient to maintain the resistance of probiotic microorganisms in the gastrointestinal (GIS) system.

\section{Sensory Properties of Erişte}

The color, taste, chewiness, cooking properties and odor sensory properties of the produced Erişte samples were evaluated by an expert jury of 8 people using a scale of 1-5 points and the consumer favorability was determined. The results obtained as a result of sensory analysis were shown in Figure 4. Among the samples, sample B had the highest total sensory score (4.28), followed by samples A (4.20) and D (3.73) while samples C (3.61) had the lowest score. Samples B had a very pleasant flavor. Samples $C$ had significantly lower values or all sensory parameters than the other samples. As a result, the probiotic Erişte sample groups (plain and vegetable supplement) were more favorable than others. 


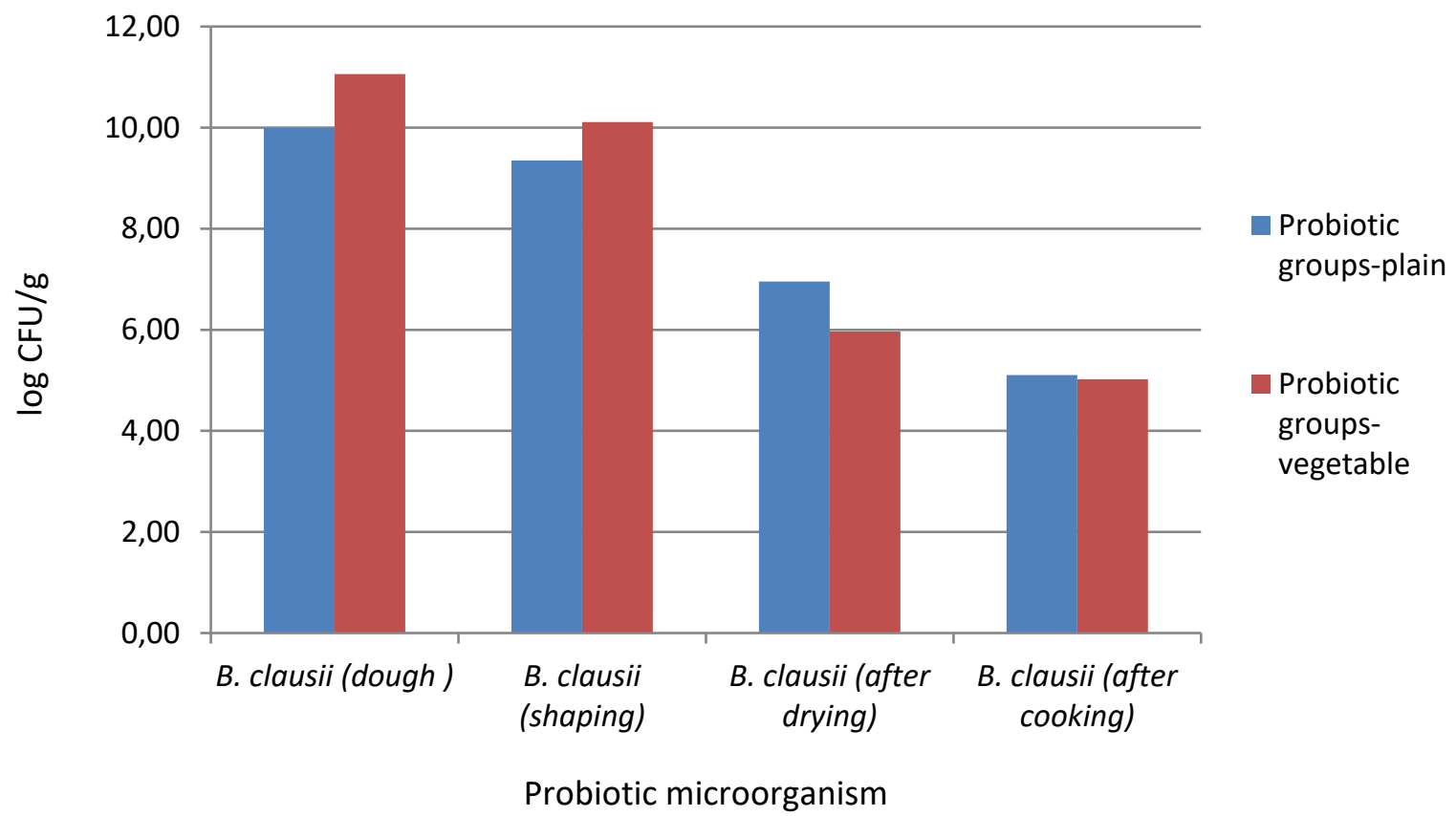

Figure 3. The number of B. clausii of probiotic Erişte (noodle) samples

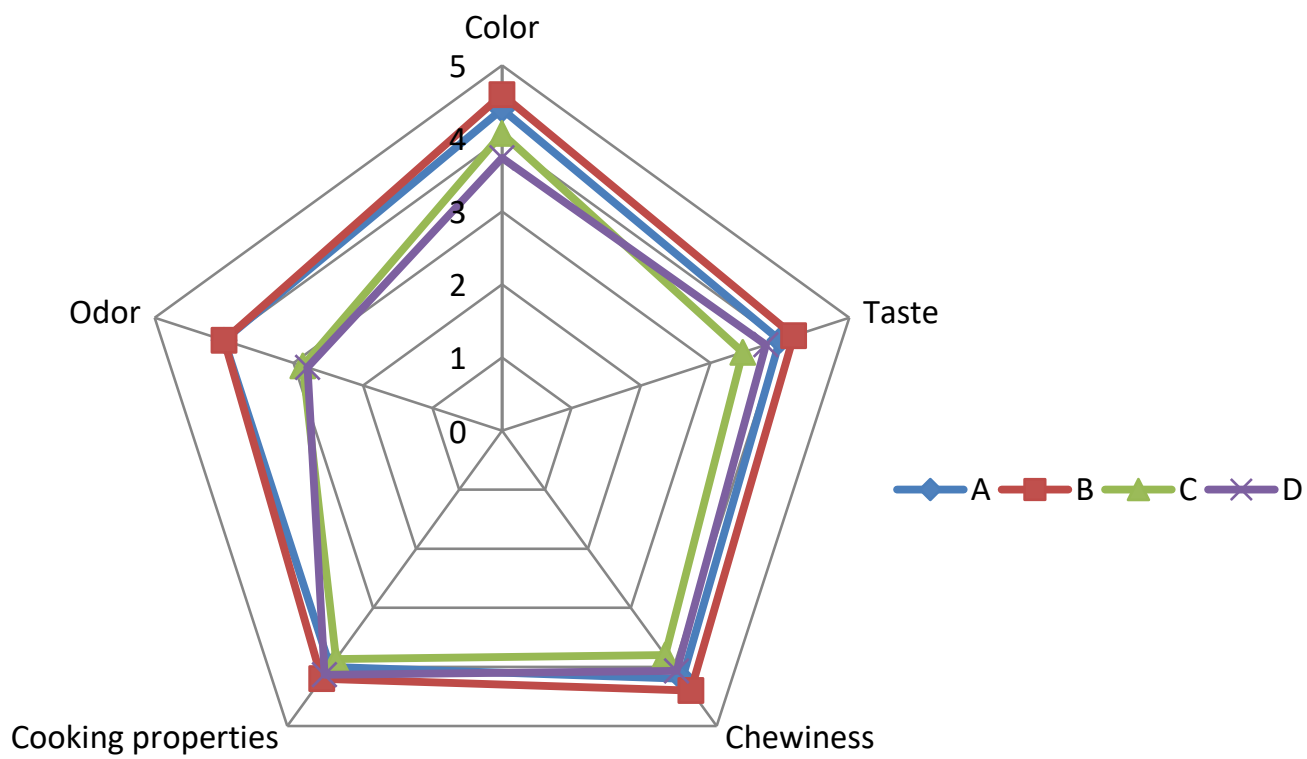

Figure 4. Sensory properties of Erişte (noodle) samples 


\section{Conclusion}

In this study, it is aimed to increase the production potential of probiotic Erişte, which are beneficial to the consumer health by maintaining or improving the intestinal microbial balance of individuals and developing a functional new product. For this purpose, the production of Erişte with the addition of B. clausii strains and enriched with vegetable aromas was carried out. As a result, it has been determined that the enriched Erişte products are in the nature of a probiotic and functional new product in accordance with the purpose of the study. It was found that the Erişte were chemical, physical and microbiologically acceptable. In terms of sensory properties, it was established that plain-probiotic Erişte were generally more favorable than plain-control group and vegetable products. The obtained results will guide future studies and contribute to the literature for about functional product development.

\section{Compliance with Ethical Standard}

Conflict of interests: The authors declare that for this article they have no actual, potential or perceived the conflict of interests.

Ethics committee approval: All authors declare that this study does not include any experiments with human or animal subjects.

Funding disclosure: This study was supported by unit of scientific research projects of Giresun University with Project No: FENBAP-A-230218-21

Acknowledgments: -

\section{References}

Baiano, A., Fares, C., Peri, G., Romaniello, R., Taurino, A.M., Siciliano, P., Gambacorta, G., Lamacchia, C., Pati, S., La Notte, E. (2008). Use of a toasted durum whole meal in the production of a traditional Italian pasta: Chemical,mechanical, sensory and image analyses. International Journal of Food Science \& Technology, 43(9), 1610-1618.

https://doi.org/10.1111/j.1365-2621.2007.01632.x

Bergman, C.J., Gualberto, D.G., Weber, C.W. (1994). Development of a high temperature dried soft wheat pasta supplemented with cowpea, cooking quality, color and sensory evelvation. Cereal Chemistry, 71(6), 523-527.

Chen, M., Chen, K., Kuo, Y. (2007). Optimal thermotolerance of Bifidobacterium bifidum in gellan-alginate microparticles. Biotechnology and Bioengineering, 98(2), 411-419. https://doi.org/10.1002/bit.21450
Chen, M.J., Chen, K.N. (2007). Applications of probiotic encapsulation in dairy products., Encapsulation and Controlled Release Technologies in Food Systems. WileyBlackwell, USA, pp. 83-107.

https://doi.org/10.1002/9780470277881.ch4

Cutting, S.M. (2011). Bacillus probiotics. Food Microbiology, 28(2), 214-220.

https://doi.org/10.1016/j.fm.2010.03.007

Demi r, B., Bi lgi ç, N., Elgün, A., Demir, M.K. (2010). Effects of chickpea flours and whole egg on selected properties of erişte, Turkish noodle. Food Science and Technology Research, 16(6), 557-564.

https://doi.org/10.3136/fstr.16.557

FDA (1995). US The Food and Drug Administration Bacte-riolological Analytical Manual. Food and Drug Administra-tion 16 th Edition, AOAC Int. Gaithersburg MD. https://www.fda.gov/Food/ FoodScienceResearch/Labora-toryMethods/ucm 1 14664.htm (accessed October 11, 2018)

Filip, S., Vidrih, R. (2015). Amino Acid Composition of Protein-Enriched Dried Pasta: Is It Suitable for a LowCar-bohydrate Diet?. Food Technology and Biotechnology, 53(3), 298-306.

https://doi.org/10.17113/ftb.53.03.15.4022

Ghaffar, S., Abdulamir, A.S., Bakar, F.A., Karim, R., Saari, N. (2009). Microbial growth, sensory characteristic and $\mathrm{pH}$ as potential spoilage indicators of Chinese yellow wet noodles from commercial processing plants. American Jour-nal of Applied Science, 6(6), 1059-1066.

https://doi.org/10.3844/ajassp.2009.1059.1066

Gouin, S. (2004). Microencapsulation: industrial appraisal of existing technologies and trends. Trends in Food Science \& Technology, 15(7-8), 330-347.

https://doi.org/10.1016/j.tifs.2003.10.005

Granato, D., Branco, G.F., Nazzaro, F., Cruz, A.G., Faria, J.A.F. (2010). Functional Foods and Nondairy Probiotic Food Development: Trends, Concepts, and Products. Comp-rehensive Reviews in Food Science, 9(3), 292-302.

https://doi.org/10.1111/j.1541-4337.2010.00110.x

Gunathilake, K.D.P.P. Abeyrathne, Y.M.R.K. (2008). Incorporation of coconut flour intowheat flour noodles and eva-luation of 1ts rheological, nutritional and sensory characteris-tics. Journal of Food Processing and Preservation 32(1), 133-142. https://doi.org/10.1046/j.1439-0361.2003.02062.x 
Hou, G., Kruk, M. (1998). Asian Noodle Technology, $A I B$ Research Technical Bulletin, 20 (12), 1-10.

Hu, X.Z., Wei, Y.M., Wang, C., Kovacs, M.I.P. (2007). Quantitative assessment of protein fractions of Chinese wheat flours and their contribution to white salted noodle quality. Food Research International, 40(1), 1-6.

https://doi.org/10.1016/j.foodres.2006.05.003

ICC Standart (2002). International Association for Cereal Science and Technology No:104, 105 and 110. https://www.icc.or.at/publications/icc-standards/standardsoverview (accessed October 15, 2018)

Iyer, C., Kailasapathy, K. (2005). Effect of co-encapsulation of probiotics with prebiotics on increasing the viability of encapsulated bacteria under in vitro acidic and bile salt conditions and in yogurt. Journal of Food Science 70(1), 1823.

https://doi.org/10.1111/j.1365-2621.2005.tb09041.x

Izydorczyk, M.S., Lagassé, S.L., Hatcher, D.W., Dexter, J.E., Rossnagel, B.G. (2005). The enrichment of Asian noodles with fibre-rich fractions derived from rollermilling of hull-less barley. Journal of the Science and Food Agriculture, 85(12), 2094-2104.

https://doi.org/10.1002/jsfa.2242

Kalkan, S., Öztürk, D., Selimoğlu, B.S. (2018). Determining some of the quality characteristics of probiotic yogurts manufactured by using microencapsulated Saccharomyces cerevisiae var. Boulardii. Turkish Journal Of Veterinary And Animal Sciences, 42, 617-623.

https://doi.org/10.3906/vet-1804-5

Karthikeyan, N., Elango, A., Kumaresan, G., Gopalakrishnamurty, T.R., Raghunath, B.V. (2014). Enhancement of probiotic viability in ice cream by microencapsulation. International Journal of Science, Environment and Technology, 3(1), 339-347.

Li, C., Lu, Q., Liu, Z., Yan, H. (2018). Effects of the addition of gluten with different disulfide bonds and sulfhydryl concentrations on Chinese white noodle quality. Czech Journal of Food Sciences, 36(3), 246-254.

https://doi.org/10.17221/326/2017-CJFS

Li, M., Zhu, K., Guo, X., Peng, W., Zhou, H. (2011). Effect of Water Activity (aw) and Irradiation on the Shelf Life of
Fresh Noodles. Innovative Food Science \& Emerging Technologies, 12(4), 526-530.

https://doi.org/10.1016/j.ifset.2011.06.005

Lu, Z.H., Li, L.T., Cao, W., Li, Z.G., Tatsumi, E. (2003). Influence of natural fermentation on physico-chemical characteristics of rice noodles. International Journal of Food Science and Technology, 38(5), 505-510.

https://doi.org/10.1046/j.1365-2621.2003.00701.x

Madene, A., Jacquot, M., Scher, J., \& Desobry, S. (2006). Flavour encapsulation and controlled release- A review. International Journal of Food Science \& Technology, 41(1), 121.

https://doi.org/10.1111/j.1365-2621.2005.00980.x

Martín, M.J., Lara-Villoslada, F., Ruiz, M.A., \& Morales, M.E. (2015). Microencapsulation of bacteria: A review of different technologies and their impacton the probiotic effects. Innovative Food Science \& Emerging Technologies, 27, 15-25.

https://doi.org/10.1016/j.ifset.2014.09.010

Ozyurt, G., Uslu, L., Yuvka, I., Gokdogan, S., Atci, G., Ak, B., Ișı, O. (2015). Evaluation ofthe cooking quality characteristics of pasta enriched with spirulina platensis. Journal of Food Quality, 38(4), 268-272.

https://doi.org/10.1111/jfq.12142

Parvez, S., Malik, K. A., Ah Kang, S., Kim, H.Y. (2006). Probiotics and their fermented food products are beneficial for health. Journal of Applied Microbiology, 100(6), 11711185.

https://doi.org/10.1111/j.1365-2672.2006.02963.x

Pınarlı, İ., İbanoğlu, Ş., Öner, M.D. (2004). Effect of storage on the selected properties of macaroni enriched with wheat germ. Journal of Food Engineering, 64(2), 249-256. https://doi.org/10.1016/j.jfoodeng.2003.10.005

Pomeranz, Y. (1998). Wheat: chemistry and technology, American Association of Cereal Chemists, Inc. St. Paul, Minnesota, USA. ISBN 13: 9780913250730

Rajam, R., Kumar, S.B., Prabhasankar, P., Anandharamakrishnan, C. (2015). Microencapsulation of Lactobacillus plantarum MTCC5422 in fructooligosaccharide and whey protein wall systemsand its impact on noodle quality. Journal of Food Science and Technology, 52(7), 4029-4041. https://doi.org/10.1007/s13197-014-1506-4 
Ross, R,P., Desmond, C., O'Callaghan, E., Fitzgerald, G., Stanton, C. (2002). Improved survival of Lactobacillus paracasei NFBC 338 in spray-dried powders containing gum acacia. Journal of Applied Microbiology, 93(6), 1003-1011. https://doi.org/10.1046/j.1365-2672.2002.01782.x

Schrezenmeier, J., de Vrese, M. (2001). Probiotics, prebiotics and synbiotics approaching a definition. The American Journal of Clinical Nutrition, 73(2), 361-364.

https://doi.org/10.1093/ajen/73.2.361s

Shewry, P.R. (2007). Improving the protein content and composition of cereal grain. Journal of Cereal Science, 46(3), 239-250.

https://doi.org/10.1016/j.jcs.2007.06.006

Siró, I., Kápolna, E., Kápolna, B., Lugasi, A. (2008). Functional food. Product development, marketing and consumer acceptance - a review. Appetite, 51(3), 456-467.

https://doi.org/10.1016/j.appet.2008.05.060

Sorokulova, I.B., Pinchuk, I.V., Denayrolles, M., Osipova, I.G., Huang, J.M., Cutting, S.M., Urdaci, M.C. (2008). The safety of two Bacillus probiotic strains for human use. Digestive Diseases and Sciences, 53(4), 954-963. https://doi.org/10.1007/s10620-007-9959-1

Sozer, N., Kaya, A. (2008). The effect of cooking water composition on textural andcooking properties of spaghetti. International Journal of Food Properties, 11(2), 351-362.

http://dx.doi.org/10.1080/10942910701409260
Ugarčić-Hardi, Ž., Jukić, M., Koceva Komlenić, D., Sabo, M., Hardi, J. (2007). Quality parameters of noodles made with various supplements. Czech Journal of Food Sciences, 25(3), 151-157.

https://doi.org/10.17221/742-CJFS

Urdaci, M.C., Bressollier, P., Pinchuk, I. (2004). Bacillus clausii Probiotic Strains Antimicrobial and Immunomodulatory Activities. Journal of Clinical Gastroenterology, 38(2), 86-90.

https://doi.org/10.1097/01.mcg.0000128925.06662.69

Vinderola, C.G., Prosello, W., Ghiberto, D., Reinheimer, J.A. (2000). Viability of probiotic (Bifidobacterium, Lactobacillus acidophilus and Lactobacillus casei) and nonprobiotic microflora in Argentinian Fresco cheese. Journal of Dairy Science, 83(9), 1905-1911.

https://doi.org/10.3168/jds.S0022-0302(00)75065-X

WHO, (2000). World Health Organization Regional Office for Europe, database of microbiological specifications for selected countries. www.euro.who.int/foodsafety/Microbiological/20020418_8 (accessed November 16, 2018)

Zhang, C., Zhang, S., Bie, X., Zhao, H., Lu, F., Lu, Z. (2015). Effects of recombinant lipoxygenase on the rheological properties of dough and the quality of noodles. Journal of the Science of Food and Agriculture, 96(9), 3249-3255.

https://doi.org/10.1002/jsfa. 7508 